\title{
The Measurement of Budget Outlays of Local Government Units for Removing the Natural Disasters' Effects - A Case of Polish Municipalities
}

\author{
Zbigniew N. Piepiora ${ }^{1}$, Marian Kachniarz ${ }^{2}$ \\ 1 Wroclaw University of Environmental and Life Sciences, Wroclaw, Poland, zbigniew.piepiora@upwr.edu.pl \\ 2 Wroclaw University of Environmental and Life Sciences, Wroclaw, Poland, marian.kachniarz@upwr.edu.pl
}

\begin{abstract}
The aim of the paper is the measurement of budget outlays of local government units for removing the natural disasters' effects in Poland at the local level of municipality in years 2008-2017. Authors formulated a hypothesis: It is possible to measure the budget outlays of local government units for removing the natural disasters' effects at the local level of municipality. Authors posed the research question: How should we measure the budget outlays of local government units for removing the natural disasters' effects at the local level of municipality? The spatial range of the subject of research covers the area of Poland. The time span of the research concerned the years 2008-2017, which is a common period for all selected features. Data analysis was based on index analysis from the group of statistical methods and cartographic method - cartogram. Cartograms were generated in the QGis 3.6.3 program. The objective of the paper was attained. The carried out analysis made it possible to answer positive the research question. This allowed to test positively the hypothesis. Constructed indicator enabled the measurement of the relation of budget outlays of local government units for removing the natural disasters' effects to the number of citizens of municipalities in Poland. In opinion of authors, the indicator should be applied in other countries. This issue requires further research at the local level of municipality.
\end{abstract}

KEYWORDS: finance, outlay, local government, natural disaster, recovery, measure, indicator, municipality

\section{Introduction}

According to EMDAT, a disaster can be defined as a 'situation or event, which overwhelms local capacity, necessitating a request to national or international level for external assistance (...) An unforeseen and often sudden event that causes great damage, destruction and human suffering. Though often caused by nature, disasters can have human origins'(EMDAT 2019). Thus, disasters resulted from natural beginnings are often called 'natural disasters'(Abbott 2009, Alexander 1999, Piepiora 2012).

Only in years 2007-2018 in the World occurred 3765 natural disasters. In examined period dominated floods (1523) and storms (1008). In Europe happened 421 natural disasters in this time. In Poland located in the center of Europe occurred 21 these kind of phenomena: 11 extreme temperatures, 6 storms and 4 floods. These 21 events affected over 100 thousand people and caused damages estimated to more than 3.5 billion US dollars (EMDAT 2019).

In the conditions of budgetary constraints, the shortage of financial means becomes a problem, so increasing the efficiency of removing the natural disasters' effects in Poland should be primarily of interest of the state and its citizens (Piepiora 2019).

The aim of the article is the measurement of budget outlays of local government units for removing the natural disasters' effects in Poland at the local level of municipality in years 20082017. Authors articulated a hypothesis: It is possible to measure the budget outlays of local government units for removing the natural disasters' effects at the local level of municipality. Authors formulated the research question: How should we measure the budget outlays of local government units for removing the natural disasters' effects at the local level of municipality?

\section{Background}

Economic efficiency is used in the literature of the subject in many contexts as allocation efficiency, cost efficiency, production efficiency, health care efficiency, investment projects efficiency and exchange efficiency etc. (Becla et al. 2012, Begg et al. 2005, Black 2003, Czechowski 1997, Kachniarz 2012, Krugman i Wells 2012, Mankiw i Taylor 2009, Milewski i Kwiatkowski 2016, Samuelson i 
Nordhaus 2009, Stiglitz and Rosengard 2015, Varian 2006, Weiss 2002, Leibenstein 1966, Rutkowska 2013, Kasprzyk 2015, Kryk 2003, Smith 1776, Pareto 1935, Bergson 1938, Hotelling 1938, Kisielewska 2005, Panzar i Willig 1981, Panzar and Willig 1977, Piepiora 2019).

Until the end of the XIX century, leading economists such as A. Smith (1776), D. Ricardo (1817) czy J. B. Say (1803) were convinced of the unlimited resources (Kryk 2003). The slightly different views expressed J.S. Mill (1848) i T.R. Malthus (1798). At the beginning of the 20th century V. Pareto [1935] basing on the theory of the 'invisible hand of the market' created a new concept of the welfare state. He pointed out the conditions of optimal allocation of resources which maximizes the prosperity of the entire economy - in the economy there is such allocation of resources which makes it impossible to improve the situation of any economic participant without simultaneously worsening the situation of at least one of the participants (Pareto's optimality principle) (Kasprzyk 2015, Kryk 2003, Smith 1776, Pareto 1935). In the year 1996 H. Leibenstein (1966) showed that in addition to efficiency in the sense of Pareto (1935), there is another type of efficiency and presented an efficiency concept type $\mathrm{X}$ which examines whether the company uses the available and disposal production factors in the most cost-effective way (Rutkowska 2013, Piepiora 2019).

However, due to the lack of data on the effects of natural disasters in BDL GUS, the measurement of budget outlays of local government units for removing the natural distaters' effects can be defined as the relation of measures spent for removing natural disasters' losses in municipalities to the numbers of citizens of each administrative unit.

\section{Materials and methods}

The spatial analysis covers the territory of Poland. The time period covered the years 2008-2017. It was a common period for all selected features.

The issues raised justified the use of an evidence-based test method. The research process was divided into two stages - analyses with deductive reasoning and synthesis with inductive reasoning. The index analysis from the group of statistical methods and cartographic method - cartogram were used to do the data analysis. It is worth noting that the cartogram is a quantitative method. It served to present the tested efficiency. Cartograms were created in the QGis 3.6.3 program.

The method of examination of documents was used to collect source materials. In the conducted research, secondary and external sources were used. The external, secondary source of information was data from the EMDAT and the BDL database of the Central Statistical Office. The EMDAT database contained features concerning on occurrence and effects only on international and national level. The BDL database enclosed data on the number of citizens in Polish municipalities and the budget outlays of local government units for removing the natural disasters' effects. It is worth noting that the Local Data Bank of the Central Statistical Office don't aggregate the features concerning the removal of natural disasters' effects according to the type of natural disaster.

\section{Results and discussions}

The first map presents the Polish municipalities and municipalities with county rights according to numbers of citizens in the year 2017. As we can see, dominate huge cities such Warszawa, Kraków, Łódź, Wrocław, Poznań, Gdańsk, Szczecin. 


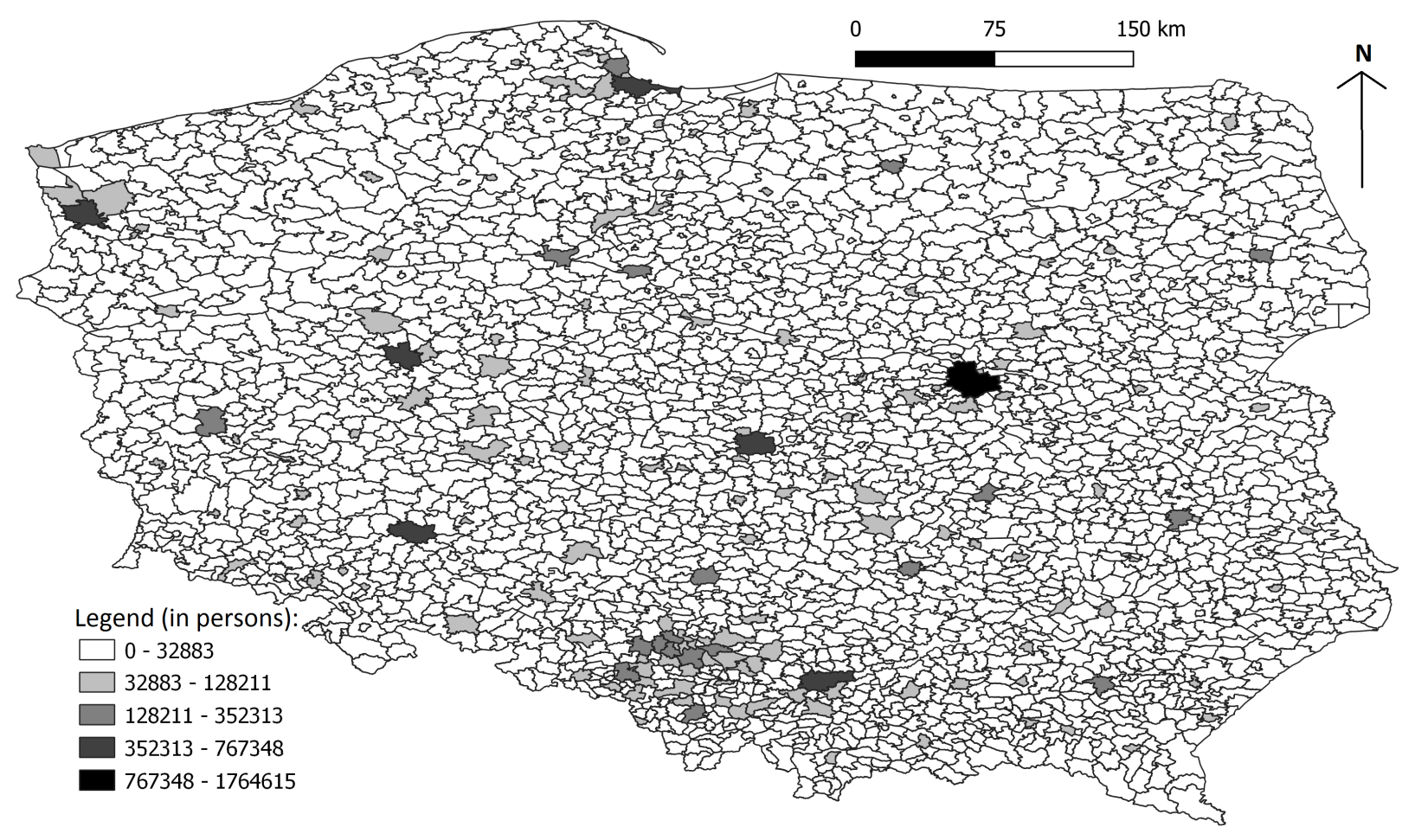

Figure 1. Number of citizens in Polish municipalities and municipalities with county rights Source: elaboration based on (BDL GUS, 2019)

The second map shows the measures spent for removing natural disasters' losses in Polish municipalities and municipalities with county rights in 2017 USD. As we can see, the largest amounts were noted in municipalities and municipalities with county rights in the south-west and south-eastern parts of Poland, and in the capitol city - Warsaw. It compares mostly with the area of the great flood that affected the examined country in the year 2010 and with the presence of flash floods and storms.

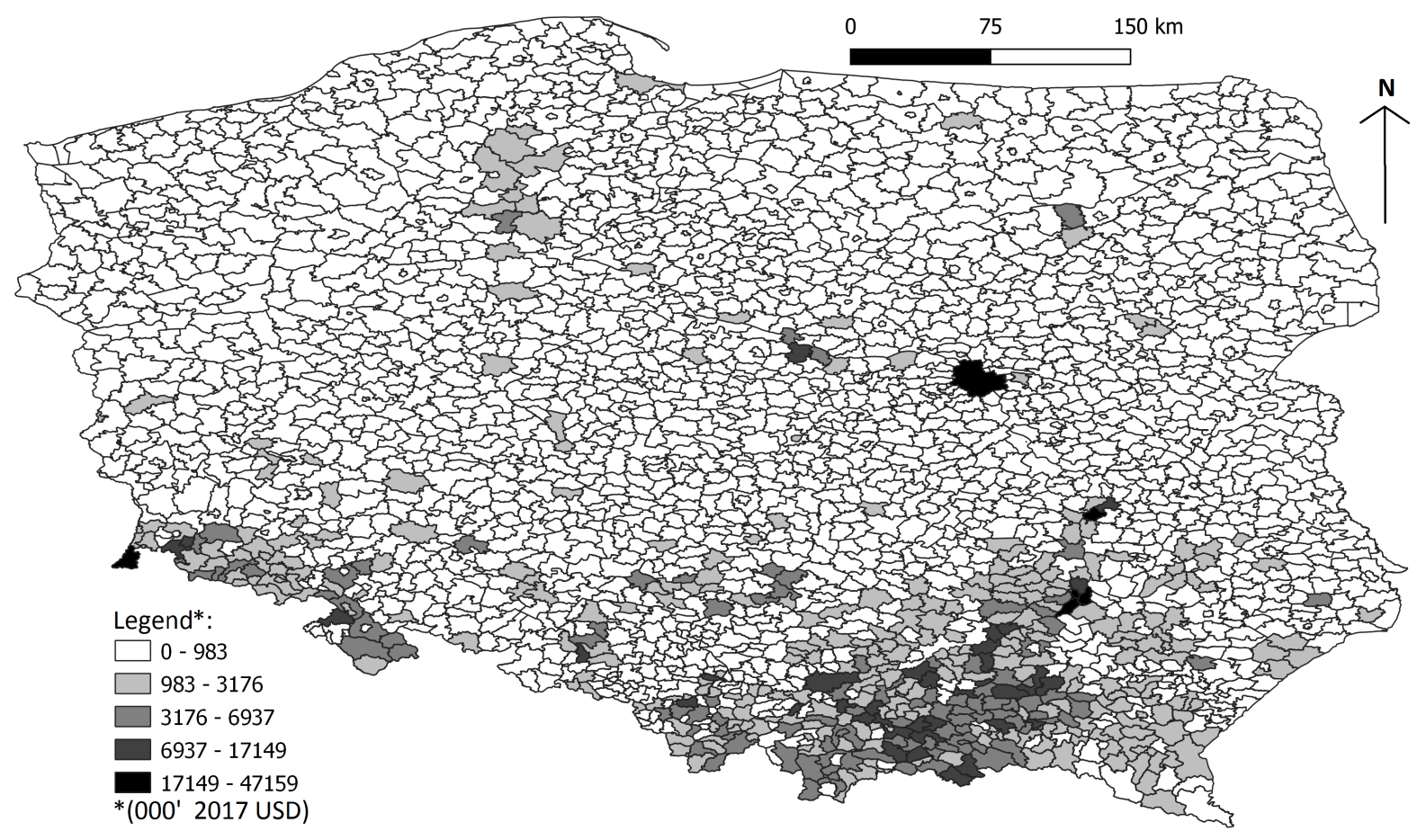

Figure 2. The measures spent for removing natural disasters' losses in Polish municipalities and municipalities with county rights in years 2008-2017 in 2017 USD

Source: elaboration based on (BDL GUS, 2019) 
The third map presents the measures spent for removing natural disasters' losses in Polish municipalities and municipalities with county rights in years 2008-2017 in 2017 USD divided by the numbers of citizens of each administrative unit in 2017. The map 3 is similar to the previous map.

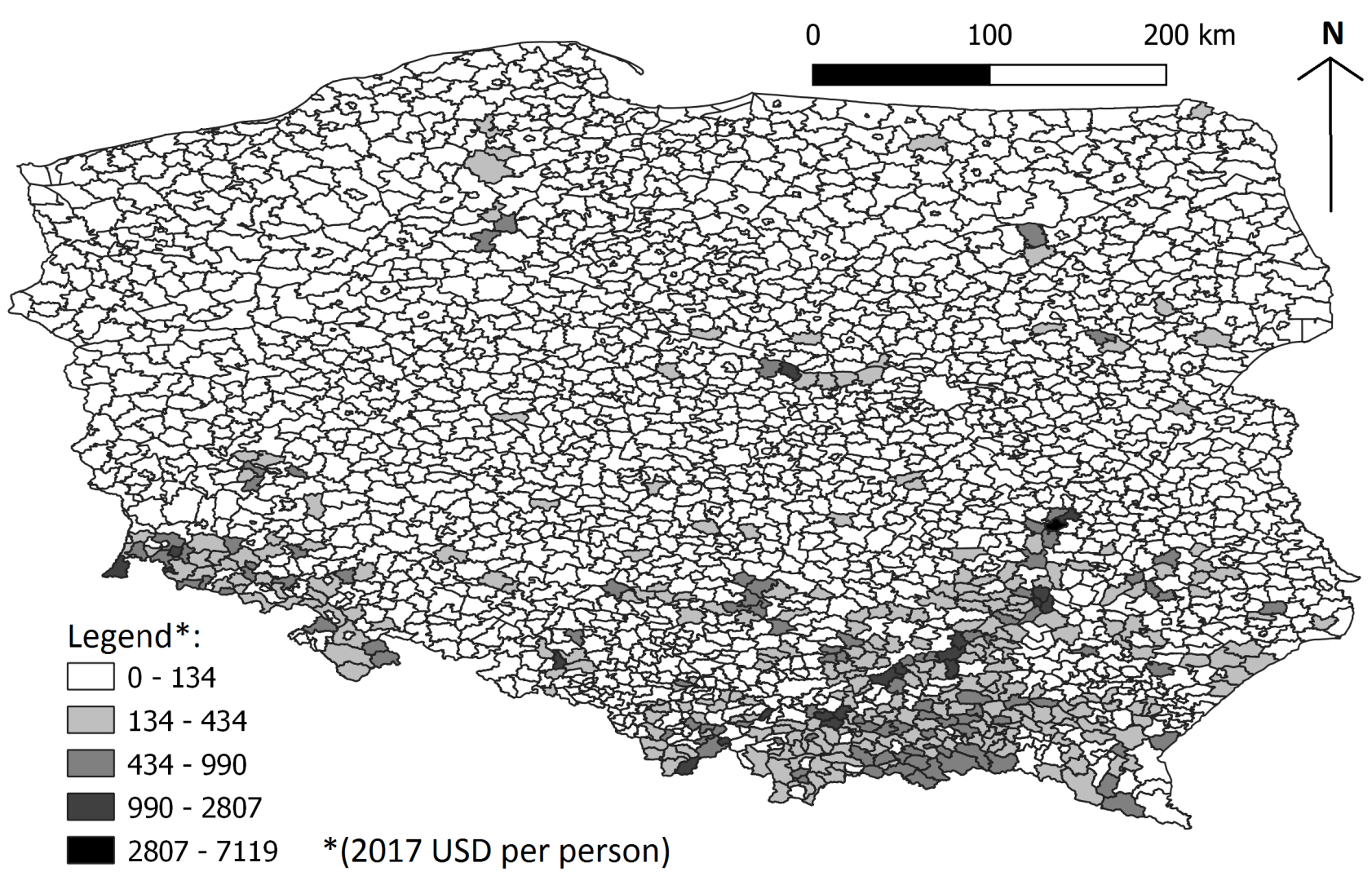

Figure 3. The measures spent for removing natural disasters' losses in Polish municipalities and municipalities with county laws in years 2008-2017 in 2017 USD divided by the numbers of citizens of each administrative unit in 2017

Source: elaboration based on (BDL GUS, 2019)

\section{Conclusions}

The objective of the paper was attained. The carried out analysis made it possible to answer positive the research question. This allowed to test positively the hypothesis. Constructed indicator enabled the measurement of the relation of budget outlays of local government units for removing the natural disasters' effects to the number of citizens of municipalities in Poland.

In opinion of authors, the indicator should be applied in other countries. It is also necessary to specify in the EMDAT the data at the local level of the municipality. According to authors, it is necessary to specify in the Local Data Bank of the Central Statistical Office the features concerning the removal of natural disasters' effects according to the type of natural disaster.

It is also necessary similar activity to do by this institution - to start aggregating data in the Local Data Bank of the Central Statistical Office in Poland regarding the damages caused by natural disasters, specifying by years, phenomena and municipalities. However, this issue requires further research at the local level of municipality.

\section{References}

Abbott P. L., 2009. Natural disasters. San Diego: San Diego State University. Alexander D., 1999. Natural disasters. Berlin: Springer Science \& Business. BDL GUS, 2017. Available at https://bdl.stat.gov.pl/BDL/start, 4.07.2017.

Becla A., Czaja S., Zielińska A. 2012. Analiza kosztów-korzyści w wycenie środowiska przyrodniczego [Cost-benefit analysis in valuation of environment]. Warsaw; Difin SA. 
Begg D., Fisher S., Dornbusch R., 2005. Economics. McGraw-Hill Education.

Bergson A., 1938. "A Reformulation of Certain Aspects of Welfare Economics." Quarterly Journal of Economics, 52 (2): 310-334..

Black J., 2003. A Dictionary of Economics, Oxford University Press.

Czechowski L., 1997. Wielowymiarowa ocena efektywności ekonomicznej przedsiębiorstwa przemysłowego [Multidimensional assessment of the industrial company's economic efficiency]. University of Gdansk.

EM-DAT, CRED / UCLouvain, Brussels, Belgium. Available at www.emdat.be (D. Guha-Sapir), accessed: 27.07.2019.

QGIS. 2019. Available at https://www.qgis.org/pl/site/forusers/download.html, accessed: 4.07.2019.

Hotelling H., 1938. "The General Welfare in Relation to Problems of Taxation and of Railway and Utility Rates." Econometrica 6 (3).

Kachniarz M., 2012. Efektywność usług publicznych - teoria i praktyka [Efficiency of public services theory and practice], Wroclaw University of Economics.

Kasprzyk, B. 2015. Problem pomiaru w ekonomii dobrobytu - poglądy historyczne i współczesne [The problem of measurement in the economy of well-being - historical and contemporary views]. Nierówności Społeczne a Wzrost Gospodarczy [Social inequalities and Economic Growth], no. 41 (1/2015), Rzeszów.

Kisielewska, M. 2005. "Charakterystyka wybranych metod pomiaru efektywności bazujących na krzywych efektywności [Characteristics of selected effectiveness measurement methods based on efficiency curves]." Research Papers of Wroclaw University of Economics, no. 4, Wrocław.

Krugman P., Wells R., 2012. Microeconomics. New York: Worth Publishers.

Kryk B., 2013. Analiza kosztów i korzyści w ocenie efektywności ekologicznej i społecznej [Cost-benefit analysis in assessing ecological and social effectiveness]. Research Papers of Wroclaw University of Economics, no. 297, Wrocław.

Leibenstein H., 1966. “Allocative Efficiency vs. 'X-Efficiency'.” The American Economic Review, Vol. 56, No. 3.

Malthus R. T., 1798. “An Essay on the Principle of Population.” London: St. Paul's Church-Yard.

Mankiw N. G., Taylor P.M., 2009. Economics. UK: Cengage Learning.

Milewski E., Kwiatkowski E., 2005. Podstawy ekonomii [Principles of economics]. PWN, Warsaw.

Mill S., 1848. Principles of Political Economy with some of their Applications to Social Philosophy. Ashley ed. London.

Panzar C. J., Willig D.R., 1981. “Economies of Scope.” American Economic Review 71 (2): $268-72$.

Panzar C. J., Willig D.R., 1977. "Economies of Scale in Multi-Output Production." Quarterly Journal of Economics 91 (3): 481-493.

Pareto V., 1935. Trattato Di Sociologia Generale [The Mind and Society]. London: Jonathan Cope Ltd.

Piepiora Z., 2012. Ekonomiczne aspekty lokalnej polityki przeciwdziałania skutkom katastrof naturalnych [Economic aspects of natural disasters policy on the local level], Kowary.

Piepiora Z., 2019. Ekonomiczna efektywność strukturalnej ochrony przeciwpowodziowej w Polsce, Uniwersytet Przyrodniczy we Wrocławiu [Economic efficiency of structural flood protection in Poland], Wrocław.

Ricardo D. C., 1817. On the Principles of Political Economy and Taxation. London: John Murray, Albemarle-Street.

Rutkowska A., 2013. Teoretyczne aspekty efektywności - pojęcie i metody pomiaru [Theoretical aspects of efficiency - the concept and methods of measurement]. Zarządzanie i finance [Management and finance], vol. 11, no. 1, part 4, University of Gdańsk, Sopot.

Samuelson A. P., Nordhaus D. W., 2009. Economics. New Delhi: McGraw-Hill Education.

Say B.J. 1803. A Treatise on Political Economy (translated by C. R. Prinsep, 1821), Boston.

Smith A., 1776. An Inquiry into the Nature and Causes of the Wealth of Nations, London.

Stiglitz E.J., Rosengard J. K., 2015. Economics of public sector. New York: W. W. Norton Company, Inc.

Varian R.H. 2006. Intermediate Microeconomics: A Modern Approach. NY: W.W.Norton \& Company.

Weiss E., 2002. "Efektywność ekonomiczna a funkcjonowanie samorządów terytorialnych w teorii ekonomii [Economic efficiency and the functioning of territorial self-governments in the theory of economics]." Gospodarka lokalna w teorii i praktyce [Local economy in theory and practice], Prace Naukowe Akademii Ekonomicznej we Wroclawiu [Research Papers of Wroclaw University of Economics] no. 939, Wroclaw. 